Research Article

\title{
Pengembangan Lembar Kerja Peserta Didik Berbasis Kontekstual pada Materi Keanekaragaman Hayati Kelas X di SMA Negeri 5 Palangka Raya
}

\author{
Maria Elisha Ortis ${ }^{1^{\star}}$, Yula Miranda ${ }^{1}$, Titin Purnaningsih ${ }^{1}$ \\ ${ }^{1}$ Program Studi Pendidikan Biologi, Fakultas Keguruan dan Ilmu Pendidikan, Universitas Palangka Raya, \\ Kota Palangka Raya, Indonesia \\ *emai: mariaeotis@gmail.com
}

Kata Kuci:

Keanekaragaman Hayati

LKPD

LKPD Kontekstual

Pengembangan LKPD

Submitted: $29 / 08 / 2020$

Revised: 09/10/2020

Accepted: 01/12/2020

\begin{abstract}
Abstrak. Lembar Kerja Peserta Didik (LKPD) berbasis kontekstual dirancang dan disusun untuk membantu peserta didik agar mampu membuat hubungan antara pengetahuan yang dimilikinya dengan penerapannya dalam kehidupan sehari-hari sehingga materi pelajaran akan menjadi lebih berarti. Penelitian ini bertujuan untuk memberikan gambaran bentuk dan mengetahui kelayakan LKPD berbasis kontekstual pada materi keanekaragaman hayati kelas $X$ di SMA Negeri 5 Palangka Raya. Penelitian ini menggunakan metode penelitian pengembangan atau Research and Development (R\&D) dengan model pengembangan ADDIE yaitu Analysis, Design, Development, Implementation, dan Evaluation. Instrumen pengumpulan data dalam penelitian ini adalah angket validasi uji ahli materi, angket validasi uji ahli media, angket validasi uji bahasa, angket respons guru dan angket respons peserta didik. LKPD diujicobakan dalam dua tahap yaitu tahap skala kecil dan skala besar. Hasil penelitian pengembangan LKPD ini telah menghasilkan produk LKPD berbasis kontekstual berbentuk buku dengan struktur yang terdiri dari (1) bagian depan yaitu sampul; judul; lembar redaksi; kata pengantar; daftar isi; daftar gambar; daftar tabel; (2) bagian isi yaitu identitas peserta didik; kompetensi dasar; tujuan pembelajaran; alat dan bahan; cara kerja; tabel pengamatan; wacana; pertanyaan; kesimpulan; (3) bagian belakang yaitu daftar pustaka; profil penulis; dan lampiran. LKPD berbasis kontekstual juga telah memenuhi kriteria sangat layak untuk digunakan dalam pembelajaran di sekolah. Hal ini ditunjukkan dari hasil persentase perolehan nilai kelayakan LKPD oleh ahli materi yaitu sebesar $83,45 \%$; ahli media yaitu sebesar $90 \%$; ahli bahasa yaitu sebesar $83,08 \%$; respons guru yaitu sebesar $91,25 \%$; dan respons peserta didik yaitu sebesar $84,37 \%$.
\end{abstract}




\section{PENDAHULUAN}

Pengembangan bahan ajar menjadi salah satu kewajiban seorang guru dalam mengembangkan kompetensi yang dimiliki. Bahan ajar dapat berupa lembar kerja peserta didik (LKPD) yang perlu dikembangkan oleh seorang guru untuk menunjang proses pembelajaran serta menciptakan suasana belajar yang menyenangkan bagi peserta didik. Pengembangan LKPD ini perlu dilakukan sebagai upaya untuk meningkatkan keaktifan peserta didik pada saat proses belajar. LKPD berbasis kontekstual dirancang dan disusun untuk membantu peserta didik agar mampu membuat hubungan antara pengetahuan yang dimilikinya dengan penerapannya dalam kehidupan sehari-hari sehingga materi pelajaran akan menjadi lebih berarti jika peserta didik mempelajari materi pelajaran yang disajikan melalui konteks kehidupan mereka, dan menemukan arti di dalam proses pembelajarannya.

Fakta di lapangan menunjukkan kegiatan pembelajaran biologi umumnya hanya mengandalkan bahan belajar dari buku sumber yang tersedia, peserta didik juga jarang melaksanakan praktikum yang mengharuskan untuk mengamati lingkungan sekitar mereka, sehingga proses pembelajaran biologi yang berlangsung seringkali hanya pembahasan materi dan soal-soal latihan yang terkait di dalamnya. Proses pembelajaran seperti ini kurang menggali keterampilan berpikir dan bertindak peserta didik yang seharusnya dapat diperoleh dari proses pembelajaran biologi. Oleh sebab itu, biologi dianggap sebagai mata pelajaran yang cenderung membosankan bagi peserta didik.

Berdasarkan hasil wawancara dengan salah satu guru mata pelajaran Biologi kelas
$X$ SMA Negeri 5 Palangka Raya, permasalahan yang dihadapi selama ini adalah keterbatasan bahan ajar berupa lembar kerja peserta didik (LKPD) yang masih belum menunjang kebutuhan belajar peserta didik. Selain itu, pada beberapa tahun belakangan juga tidak pernah dilakukan praktikum karena ruang laboratorium dialihfungsikan sebagai ruangan kelas untuk proses belajar mengajar. Sehingga dibutuhkan panduan kegiatan agar proses pembelajaran menjadi terarah dan sistematis sesuai dengan metode ilmiah yang pelaksanaannya mudah dan tidak mengharuskan untuk berada di ruang laboratorium.

Peneliti beranggapan bahwa pembelajaran biologi akan menarik dan lebih bermakna apabila peserta didik bisa langsung belajar dari alam, tidak hanya diberi konsep dan hafalan-hafalan yang terdapat pada materi yang akan dipelajari. Untuk itu diperlukan adanya bahan ajar yang dapat menuntun peserta didik untuk belajar aktif. Salah satu bahan ajar berupa lembar kerja peserta didik (LKPD). LKPD merupakan salah satu sumber belajar yang dapat dikembangkan oleh pendidik sebagai fasilitator dalam kegiatan pembelajaran (Widjajanti, 2008).

LKPD perlu dikembangkan dengan menggunakan pembelajaran kontekstual, karena materi pelajaran akan menjadi lebih berarti jika peserta didik mempelajari materi pelajaran yang disajikan melalui konteks kehidupan mereka, dan menemukan arti di dalam proses pembelajarannya (Triasi, 2019). Salah satu materi biologi kelas $X$ yang dipelajari peserta didik adalah Keanekaragaman Hayati. Materi keanekaragaman hayati ini merupakan materi yang mempelajari tentang suatu area yang menyangkut keragaman di dalam dan 
diantara organisme hidup, kumpulan organisme, komunitas biotik dan proses biotik, yang masih bersifat alamiah maupun yang sudah diubah oleh manusia (DeLong, 1996). Sehingga materi ini dirasa sangat cocok apabila digunakan untuk pengembangan LKPD berbasis kontekstual karena berhubungan langsung dengan kehidupan nyata sehingga peserta didik dapat memperoleh pengetahuan baru melalui pembelajaran yang akan dilakukan.

\section{METODE}

Penelitian ini menggunakan metode penelitian pengembangan atau Research and Development (R\&D). Pengembangan produk pembelajaran yang digunakan dalam penelitian ini mengacu pada model pengembangan ADDIE. Model ini terdiri dari lima fase atau tahapan utama, yaitu Analysis, Design, Development, Implementation, dan Evaluation. Produk yang dikembangkan dalam penelitian ini adalah LKPD berbasis kontekstual pada materi Keanekaragaman Hayati yang diimplementasikan dalam dua tahap uji coba yaitu uji coba skala kecil dan uji coba skala besar pada peserta didik kelas $X$ MIPA 3 di SMA Negeri 5 Palangka Raya.

Instrumen pengumpulan data dalam penelitian ini mengenai penilaian dari validasi terhadap LKPD berbasis kontekstual oleh validator digunakan angket validasi uji ahli materi, angket validasi uji ahli media, angket validasi uji bahasa, angket respons guru dan angket respons peserta didik.

Teknik analisis yang dilakukan adalah wawancara dan angket. Wawancara digunakan peneliti untuk mengumpulkan data pada studi pendahuluan. Instrumen pedoman wawancara dalam penelitian ini ditujukan kepada guru Biologi di SMA Negeri 5 Palangka Raya. Wawancara dilakukan peneliti terhadap guru bertujuan untuk menggali proses pembelajaran serta kondisi peserta didik kelas $X$ dalam mengikuti pembelajaran Biologi khususnya pada materi keanekaragaman hayati. Angket digunakan untuk mengetahui respons dari ahli materi, ahli media, ahli bahasa, respons guru dan respons peserta didik mengenai pengembangan LKPD berbasis kontekstual untuk mengetahui kelayakan produk sebagai dasar untuk merevisi produk.

\section{HASIL DAN PEMBAHASAN}

Aspek kelayakan materi memperoleh skor sebesar 83,45\% dengan kategori sangat layak untuk digunakan. Aspek yang digunakan dalam penilaian materi meliputi: aspek didaktik, aspek kelayakan penyajian, aspek kelayakan isi, dan aspek pendekatan kontekstual. LKPD ini dikatakan layak karena isi materi yang dimuat di dalamnya dinilai mempermudah peserta didik untuk belajar dan mudah digunakan untuk proses pembelajaran. Hal ini dikuatkan oleh pendapat peserta didik yang memberikan respons setuju terbanyak pada pernyataan butir ke 5 dan 6 . Namun, ada beberapa peserta didik yang menyatakan kurang setuju pada pernyataan butir 3 dan 4 . Hal itu disebabkan karena pada LKPD ini, tingkat keanekaragaman hayati yang diamati hanya terbatas pada tumbuhan saja, tidak mencakup hewan dan juga ekosistem.

Aspek kelayakan media memperoleh skor sebesar $90 \%$ dengan kategori sangat layak untuk digunakan. LKPD ini dikatakan layak karena media yang digunakan di dalamnya sudah memenuhi standar kurikulum sehingga menarik dan memotivasi peserta didik untuk belajar. Hal ini dikuatkan oleh pendapat banyaknya 
peserta didik yang memberikan respons setuju pada pernyataan butir 2 .

Aspek kelayakan bahasa memperoleh skor sebesar 83,08\% dengan kategori sangat layak untuk digunakan. LKPD ini dikatakan layak karena bahasa yang digunakan di dalamnya bersifat komunikatif sehingga mudah dipahami oleh peserta didik. Hal ini dikuatkan oleh pendapat banyaknya peserta didik yang memberikan respons setuju pada pernyataan butir 7 . Sedangkan menurut ahli bahasa, kualitas ketepatan struktur kalimat sudah baik karena memiliki memiliki informasi yang ingin disampaikan. Istilah yang digunakan dalam LKPD yang dikembangkan juga telah sesuai dengan $\mathrm{KBBI}$ dan atau istilah teknis yang telah baku digunakan dalam Biologi. LKPD memiliki konsistensi penggunaan istilah, simbol, dan ikon yang baik untuk mempermudah peserta didik dalam menggunakan LKPD dan mendorong peserta didik menjadi aktif dalam proses pembelajaran.

Respons guru Biologi terhadap LKPD hasil pengembangan memperoleh skor sebesar 91,25\% dengan kategori sangat layak untuk digunakan. Menurut guru, LKPD telah memiliki kesesuaian penggunaan materi, media, dan bahasa dengan materi yang akan dibahas dengan catatan perbaikan yaitu tumbuhan yang digunakan sebagai contoh pada lampiran sebaiknya tumbuhan yang pada umumnya diketahui oleh peserta didik untuk mempermudah praktikum yang akan dilakukan.

Tahap uji coba skala kecil merupakan tahap pertama setelah produk selesai dikembangkan untuk kemudian diuji keterpakaian bahan ajar berupa LKPD berbasis kontekstual hasil pengembangan melalui uji coba lapangan skala kecil dengan jumlah peserta didik sebanyak 9 orang yang terdiri dari 3 kelompok yang ditentukan secara acak. Berdasarkan uji coba skala kecil yang dilakukan, hasil respons peserta didik terhadap produk LKPD berbasis kontekstual menunjukkan respons yang positif dengan 71,25\% peserta didik yang menyatakan produk yang dikembangkan menarik dari segi tampilan dan isi karena rancangan percobaan pada LKPD ini terstruktur dan jelas sehingga mudah dipahami.

Tahap uji coba skala besar merupakan tahap akhir setelah produk dikembangkan. LKPD berbasis kontekstual digunakan peneliti dalam proses pembelajaran, setelah selesai proses pembelajaran peneliti meminta peserta didik untuk mengisi angket yang telah disiapkan. Dalam pengembangan LKPD berbasis kontekstual ini, tidak hanya hasil respons peserta didik pada uji skala kecil yang digunakan akan tetapi respons peserta didik sebagai pengguna produk juga sangat mempengaruhi pada uji skala besar. Uji coba skala besar melibatkan 35 peserta didik. Persentase rata-rata perolehan skor berdasarkan analisis data pada uji skala besar adalah 84,37\% dan berdasarkan tabel kriteria masuk dalam kriteria sangat layak untuk digunakan dalam proses pembelajaran.

\section{KESIMPULAN}

Pengembangan LKPD ini telah menghasilkan produk LKPD berbasis kontekstual pada pembelajaran materi keanekaragaman hayati sub topik tingkat keanekaragaman hayati yang berbentuk buku dengan struktur LKPD yang terdiri dari (1) bagian depan yaitu sampul; judul; lembar redaksi; kata pengantar; daftar isi; daftar gambar; daftar tabel; (2) bagian isi yaitu identitas peserta didik; kompetensi dasar; tujuan pembelajaran; alat dan bahan; cara kerja; tabel pengamatan; wacana; 
pertanyaan; kesimpulan; (3) bagian belakang yaitu daftar pustaka; profil penulis; dan lampiran. Produk LKPD berbasis kontekstual pada pembelajaran materi keanekaragaman hayati sub topik tingkat keanekaragaman hayati telah memenuhi kriteria sangat layak untuk digunakan dalam pembelajaran di sekolah. Hal ini berdasarkan hasil persentase perolehan nilai kelayakan LKPD oleh ahli materi yaitu sebesar 83,45\%; ahli media yaitu sebesar $90 \%$; ahli bahasa yaitu sebesar $83,08 \%$; respons guru yaitu sebesar 91,25\%; dan respons peserta didik yaitu sebesar $84,37 \%$.

\section{Referensi}

DeLong, D.C. (1996). Defining Biodiversity. USA: Wildlife Society Bulletin.

Triasi, Meylisa. (2019). Pengembangan LKPD Berbasis Kontekstual Pada Mata Pelajaran IPA Materi Pencemaran Lingkungan Untuk Meningkatkan Hasil Belajar Peserta Didik Kelas VII SMP Negeri 16 Palangka Raya. Palangka Raya: Universitas Palangka Raya.

Widjajanti, Endang. (2008). Kualitas Lembar Kerja Siswa. Yogyakarta: Universitas Negeri Yogyakarta. 